\title{
A música, nossa percursora. Acerca da música na filosofia de Nietzsche
}

\author{
Maria João Branco*
}

\begin{abstract}
Resumo: O propósito deste artigo é procurar estabelecer as razões do privilégio da música na filosofia de Nietzsche. Através da apresentação da noção de "música absoluta" e do seu lastro na estética moderna, nomeadamente em Schopenhauer e nos textos teóricos de Wagner, mostrar-se-á as razões do distanciamento de Nietzsche dessa mesma noção, esclarecendo como a sua crítica de uma "metafísica da música" dá lugar à compreensão da escuta musical como um exercício de liberdade que promove o pensamento filosófico.

Palavras-chave: música - filosofia - linguagem - liberdade - Wagner
\end{abstract}

A nossa música foi até agora tão grande, tão boa: nela, nada era impossível! Que ela mostre então que é possível sentir de uma só vez estas três coisas: elevação, luz profunda e quente e a felicidade da suprema coerência (M/A 461, KSA 3.277-8).

1 .

Aquilo a que podemos chamar a inclinação musical de Nietzsche é bem conhecida, tal como é sabido o lugar central que a música ocupou, quer no seu pensamento, quer na sua vida. $\mathrm{O}$ privilégio que Nietzsche concedeu à música é consensual entre os mais diversos comentadores, embora essa interpretação se baseie

* Professora do Instituto de Filosofia da Linguagem (IFL) da Universidade Nova de Lisboa (UNL), Lisboa, Portugal. E-mail: maria_joao_branco@yahoo.com. 
amiúde mais na biografia do filósofo do que na análise dos textos que escreveu. O propósito deste artigo é procurar estabelecer as razões do privilégio da música na filosofia de Nietzsche a partir da sua obra. E para tal importa começar, porém, por ressalvar que não é verdade que Nietzsche não se interessou pelas outras artes, em particular pelas artes visuais. E não é verdade, em primeiro lugar, porque, como se procurará mostrar, uma das consequências e dos pressupostos do pensamento de Nietzsche sobre a música é a ideia de que ela não pode e não deve ser entendida em si, quer dizer, como um domínio autónomo e independente, "puro" ou "absoluto", encerrado em si próprio. Em segundo lugar, e talvez ainda mais decisivamente, porque talvez não seja de todo possível pensar a música (ou qualquer género artístico) sem referência às outras artes ou, pelo menos, sem relação a qualquer coisa que a música não é. Em terceiro lugar, porque o interesse de Nietzsche pelas artes visuais, pela literatura ou pelas artes hoje ditas "performativas" é evidente desde $O$ nascimento da tragédia, dele sendo testemunhas inúmeras passagens sobre a pintura, a arquitectura, o teatro, a dança ou a poesia, quer nas obras publicadas, quer nos fragmentos póstumos. Na obra de Nietzsche podemos encontrar, portanto, um pensamento profundo acerca de cada género artístico a partir de referências a artistas concretos e a obras específicas nas quais fundou as suas apreciações e considerações filosóficas ${ }^{1}$. Por

1 Sobre a relação de Nietzsche com a música, cf. a biografia já clássica de Curt Paul Janz (que desenvolve, ao longo dos três volumes, com muito pormenor, a relação de Nietzsche com a música desde a infância, a importância da música na sua obra, a sua capacidade de improvisação ao piano, bem como, evidentemente, a relação com Wagner e todas as suas consequências na vida e na obra do filósofo), e também a biografia, mais recente, de Rüdiger Safranski, onde o autor defende que "se pode dizer que toda a filosofia de Nietzsche é a tentativa de deter [a música] na vida" e que "mesmo quando a música já terminara, Nietzsche queria, tanto quanto possível, fazer música com a linguagem, os pensamentos e os conceitos." (p. 9) - SAFRANSKI, R, Nietzsche. Biographie seines Denkens. Frankfurt am Main: Fischer Taschenbuch Verlag, 2005. Por seu lado, Georges Lièbert defendeu (de um modo que nos parece duvidosamente sustentável) que "Nietzsche nunca pensa a música - porque ela é impensável, felizmente impensável, teria ele podido dizer - é a partir dela que ele pensa", e que desde MA/HH até FW/GC "é contra a música que Nietzsche filosofa" (p. 202). Cf. 
esta razão, a musicofilia de Nietzsche de modo nenhum deve ser confundida com uma idolatria da música (ou "musicolatria", na expressão forjada por Lacoue-Labarthe ${ }^{2}$ ) no sentido de um desprezo ou de uma indiferença pelas outras artes.

Entre outras razões, o interesse de Nietzsche pela música e a relação privilegiada que a sua filosofia estabeleceu com esta arte são certamente também devedores de razões de ordem histórica, que dizem respeito tanto à história da música erudita ocidental, como à história da própria filosofia moderna e, em particular, à história da filosofia alemã $\tilde{a}^{3}$ Pensando nesse contexto histórico-filosófico, não será certamente abusivo defender que, provavelmente desde Kant, a música se tornou num objecto privilegiado da reflexão estética e filosófica. A este fato não são alheios dois aspectos que parecem

LIÉBERT, G. Nietzsche et la musique. Paris: PUF, 2000. Contrapondo-se de modo muito consistente à leitura de Liébert, Éric Dufour argumentou que "Nietzsche é um filósofo que procurou durante toda a sua vida pensar a música, dar um estatuto conceptual à música" (p.13), mas para este comentador "Nietzsche era absolutamente indiferente às artes visuais" (p. 17), o que mostra aos textos que provam o contrário. Cf. DUFOUR, É. L'esthétique musicale de Nietzsche. Presses Universitaires du Septentrion, 2005. Dufour contraria ainda a tese de Kessler, para o qual a partir de MA/HH a música perde o seu privilégio para as artes plásticas, considerando Nietzsche a música como uma arte imitativa e figurativa, o que é um evidente desvio do espírito e da letra dos textos (Cf. KESSLER, Mathieu, L'esthétique de Nietzsche, PUF, Paris, 1998, p. 191-205). Também Luis de Santiago Guervós parte do "paradigma estético da música" no seu estudo sobre a estética de Nietzsche, não descurando porém o lado artístico da linguagem, e sobretudo a importância que a dança reveste no pensamento estético de Nietzsche. Cf SANTIGO GUERVÓS, L. Arte y Poder. Aproximación a la estética de Nietzsche. Madrid: Trotta, 2004. Por seu lado, no estudo Nietzsche und die Kunst, Theo Meyer dedica um capítulo exclusivo à arquitectura e à pintura e outro à poesia no pensamento de Nietzsche, defendendo embora que "em comparação com o entusiasmo de Nietzsche pela música, o seu interesse pelas artes plásticas era parco", e que, ao contrário de Goethe, "Nietzsche não era um homem do olhar". MEYER, T. Nietzsche und die Kunst. Tübingen/ Basel: Francke Verlag, 1993, p. 105. Volker Gerhardt é um dos poucos comentadores a mencionar a admiração de Nietzsche por pintores como Rafael, Dürer ou Claude Lorrain no artigo "Pathos und Distanz" (Cf. GERHARDT, V. Pathos und Distanz. Studien zur Philosophie Friedrich Nietzsches. Stuttgart, Reclam, 1988, p. 5-11).

2 LACOUE-LABARTHE, P. Musica ficta (Figures de Wagner). Paris: Christian Bourgois, 1991, p. 203.

3 A este respeito, cf. os estudos reunidos no volume HERMAND, J.; RICHTER, G. (eds.), Sound Figures of Modernity. German Music and Philosophy, The University of Wisconsin Press, Wisconsin / London, 2006. 
caracterizar de modo essencial a música: ela é, por um lado, uma arte não representativa ou "isenta de imagens" (GT/NT 1, KSA 1.25-30 $)^{4}$ e, por outro, uma arte desprovida de palavras, quer dizer, a música não é nem visível, nem conceptual. Daí resultou que a filosofia a tenha considerado, quer depreciativamente, como uma expressão humana deficiente que "não deixa nada para pensar" (Kant), quer, pelo contrário, como a arte que supera as restantes pelo seu estatuto metafísico, mostrando ao mesmo tempo os próprios limites da filosofia (Schopenhauer). No entanto, mesmo quando a depreciaram, os filósofos sempre reconheceram à música um poder sobre os homens que age como uma ameaça à racionalidade e, portanto, à própria possibilidade do pensamento. E é nesta medida que se pode talvez dizer que a música pode, de um modo a que Nietzsche foi sensível, pôr em risco a filosofia, ou que a música é "por excelência, o objecto rebelde ao domínio filosófico" porque "não cessa de indicar um limite da filosofia, um obstáculo secreto ao seu pleno desenvolvimento" .

Porquê um limite? Uma resposta muito sumária seria a de que a música resiste à reunião sob uma autoridade única - linguística, conceptual ou de inteligibilidade -, obrigando, até, os seus ouvintes à experiência da disjunção de uma unidade (em notas musicais, intervalos, intensidades, etc.) a que a escuta musical os expõe. A música pode ser definida como um convívio de diferentes diferido no tempo e escutá-la é precisamente aceder à experiência dessa diferença ou diferenciação. Assim se pode dizer que, para pensar a música, a filosofia tem de renunciar à vontade de a dominar conceptualmente e isto significa, não renunciar a pensá-la, mas a

4 Sempre que não exista tradução portuguesa do texto citado, referir-nos-emos à edição NIETZSCHE, F. Sämtliche Werke, Kritische Studienausgabe, herausgegeben von Giorgio Colli und Mazzino Montinari, Deutscher Taschenbuch Verlag, Walter de Gruyter, Berlin, 1999, assumindo plena responsabilidade pela versão portuguesa proposta; caso contrário, a referência será a edição portuguesa das Obras Escolhidas (Lisboa: Círculo de Leitores, 1996), dirigida por António Marques.

5 LACOUE-LABARTHE, P., op. cit., p. 165-166. 
pretender controlá-la ou determiná-la fixando-a em conceitos. E aqui reside o problema, se é verdade que é precisamente isto que a filosofia faz: interpretar o mundo remetendo as diferenças singulares para conceitos gerais que os filósofos criam ou determinam procurando dar inteligibilidade ao que os rodeia. Efectivamente, para além de as interrogar e de as pôr em questão, a filosofia chama nomes às coisas ou, como escreveu Nietzsche, a filosofia "legisla" (JGB/BM 204 e 211, KSA 5.129 e 144-5), a isso chamando "conhecer". Isto implica que ela está e estará sempre dependente daquilo de que a música parece estar livre, ou seja, das limitações da linguagem. Contudo, e na medida em que lhe é mais próprio perguntar do que responder, para além de legislar, de dar nomes às coisas, a filosofia não deixa também de se pôr continuamente em causa a si mesma, quer dizer, de se interrogar acerca de si própria e de questionar as interpretações que faz, os conceitos que cria. Pode mesmo dizer-se que é essa a sua vida, no sentido em que foi sempre essa a sua história e que é nesse contínuo movimento crítico - a que Nietzsche chamou Selbstüberwindung — que ela se constitui. A filosofia está e tem de estar sempre a superar-se, ou seja, ela está e tem de estar sempre a nascer a partir da rebeldia ou liberdade com que as coisas se furtam ao seu domínio, sendo, por sua vez, também ela livre ou rebelde em relação aos seus próprios resultados.

Dizer que a música é um objecto rebelde ao pensamento filosófico, corresponde talvez a dizer que provavelmente a música não é propriamente um objecto e que, para a pensar, a filosofia tem de a ouvir, ou seja, suspender (e superar) precisamente a dicotomia entre os conceitos de sujeito e objecto do conhecimento numa experiência em que estes termos parecem conhecer ou manifestar os seus limites. E a questão que se coloca, então, é a de saber como é que, pensando nos limites, que são também os limites da linguagem, a filosofia se transforma num exercício de liberdade. Este problema define em grande medida o quadro geral no qual se desenvolveu a filosofia moderna e explica, porventura, o interesse desta última 
pela música ${ }^{6}$. Pondo em causa os conceitos de sujeito e de objecto, a experiência da escuta musical legitima o questionamento da definição do sujeito como instância auto-sustentada e a sua determinação como fundamento do próprio pensamento num mundo desprovido de um ponto de apoio divino. De facto, a experiência de ouvir música parece acentuar as fragilidades desse mesmo conceito de sujeito, indicando, em particular, esferas que ele não controla e que, ao invés, ameaçam a sua presunção de autonomia e liberdade.

A filosofia de Nietzsche inscreve-se na linhagem da filosofia moderna e destes problemas que a caracterizam. $\mathrm{O}$ seu interesse pela música implica que esta arte oferece à filosofia instrumentos privilegiados para questionar a ideia da autonomia do sujeito, para determinar a relação da linguagem com o mundo e também para pensar o que é pensar. Na música Nietzsche encontrou a arte que parece mostrar do modo mais claro o sentido do mote da sua filosofia porque a experiência musical põe em causa tanto a oposição entre sujeito e objecto, como entre pensamento e experiência ou entre ser e devir. Por outro lado, a sua reflexão sobre a música contribuiu certamente para o modo como Nietzsche pensou a linguagem e para a sua compreensão de que a relação entre as palavras e as coisas não pode ser explicada como uma relação entre instâncias fixas e significados linguísticos que as representam. Para Nietzsche, a nossa compreensão das coisas depende do tipo de relações em que estão com as outras coisas e isso significa que, em vez de olhar o mundo 'atomisticamente' como uma série de objectos discretos, Nietzsche se preocupou em pensá-lo como uma rede de relações na qual aquilo que as coisas são também depende de como falamos sobre elas ${ }^{7}$. No que à música diz, muito concretamente, respeito,

6 Uma análise bastante exaustiva das relações da filosofia moderna e do quadro dos seus problemas pode ser encontrada na obra de BOWIE, A. Music, Philosophy and Modernity. Cambridge University Press, 2007.

7 FW / GC 354 é particularmente esclarecedor daquilo a que me refiro. Sobre esta noção de "rede" e sua relação com a compreensão nietzschiana da linguagem, permito-me remeter para os ensaios do volume recentemente editado CONSTÂNCIO, J./ BRANCO, M.J.M. (eds.), 
como procuraremos mostrar, Nietzsche considerou que ela permite aceder a uma experiência que nos liga de formas novas a aspectos do mundo e de nós mesmos, potenciando assim um alargamento da rede de significações linguisticamente estabelecida e tornando, portanto, possível um alargamento do próprio exercício de pensar. Por outro lado ainda, o facto de a música convocar aspectos da experiência humana que a razão e a linguagem não podem antecipar nem determinar de modo prévio e, sobretudo, o facto de a escuta musical convocar a experiência da transitoriedade, de um ser em devir, justifica o seu privilégio na filosofia nietzschiana. É o que tentaremos mostrar aqui e que poderíamos anunciar deste modo: a música desestabiliza a racionalidade e as fixações conceptuais já estabelecidas na medida em que é capaz de nos fazer experimentar mostrar os limites daquelas, apresentando-nos, simultaneamente, a possibilidade de alargar esses mesmos limites no interior da experiência possível.

2.

Interessa, desde logo, recordar que Nietzsche começou por considerar o que acima designámos como um alargamento do pensar - ou seja, o próprio exercício da filosofia - a partir da experiência do espectador da tragédia grega. A tese d'O Nascimento da tragédia é a de que essa experiência mostrava à razão os seus limites levando esta última, não a negar, mas a afirmar a existência. Ora, na apresentação que Nietzsche faz da tragédia, a música é um elemento essencial. E embora nessa obra Nietzsche tivesse pensado a música tanto a partir da filosofia de Schopenhauer, como

As the Spider Spins: Essays on Nietzsche's Critique and Use of Language, Berlin/ Boston/NY, Walter de Gruyter, 2012. 
da obra de Wagner, as suas posições sobre a arte a que chamou "dionisíaca" não se confundem com as daqueles autores, como devemos começar por esclarecer.

Em relação ao primeiro, importa recordar que a aparente contradição entre a declaração da secção 16 d'O Nascimento da tragédia, segundo a qual "de acordo com a doutrina schopenhaueriana", Nietzsche entende a música "como sendo a linguagem da vontade" e a afirmação posterior, na secção 215 de Humano, demasiado humano, de que a música "não fala da vontade, nem da coisa em si" se esbate nas palavras de um fragmento escrito em 1871 (KSA 7. 359-369, Nachlass/FP 12[1]), que indicam já um desvio da "metafísica da música" defendida por Schopenhauer ${ }^{8}$. Aquele texto denuncia uma perspectiva crítica tanto em relação ao conceito de vontade ${ }^{9}$, como a uma concepção metafísica da música, defendendo aí Nietzsche explicitamente que a música nasce do canto lírico, ou seja, que a sua origem é humana e não metafísica ${ }^{10}$, e que, portanto, o âmbito musical não possui originalmente uma autonomia em relação ao âmbito da linguagem humana. Ora, era justamente esta a tese de Schopenhauer, que concebeu a música como sendo uma arte totalmente independente da esfera representativa e conceptual ou linguística e que, por essa mesma razão, a música era capaz de expressar a realidade invisível que sustenta o mundo das representações (a "Vontade"), possuindo uma dignidade ontológica superior à das outras artes. $\mathrm{O}$ pensamento de Schopenhauer acerca

8 A este respeito cf. LACOUE-LABARTHE, P, "Le détour" in Le sujet de la philosophie (Typographies I), Aubier-Flammarion, Paris, 1979, p. 31-74 e DUFOUR, É, op. cit., cap. IV "La 'métaphysique de la musique' dans la Naissance de la tragédie”, pp. 72-97.

9 Declara aí Nietzsche: «toda a vida dos instintos, o jogo dos sentimentos, sensações, afectos, actos da vontade só nos é conhecida — devo aqui acrescentar contra Schopenhauer —, mesmo na introspecção mais precisa, como representação e não segundo a sua essência: e é-nos permitido dizer que a própria «vontade» de Schopenhauer não é senão a forma mais geral da manifestação do fenómeno [Erscheinungsform]». (KSA 7.361, Nachlass/FP 12 [1]). 10 «Em todos os povos a música começa sempre na ligação com a poesia lírica, e muito antes que pudéssemos pensar numa música absoluta ela percorreu nesta ligação os estádios mais importantes do seu desenvolvimento.» (KSA 7.360, Nachlass/FP 12 [1]). 
da música situa-se no prolongamento do contexto estético-musical romântico estabelecido por autores como Wackenroder, Schlegel, Tieck ou Novalis e da discussão do conceito de música absoluta e da ideia da autonomia da música instrumental relativamente a qualquer discurso conceptual ${ }^{11}$. Tal como para os românticos, para Schopenhauer a invisibilidade e a indeterminação conceptual que é própria da música não equivalia a uma insuficiência, sendo antes uma garantia de que o que era representado musicalmente não coincidia com as aparências empíricas. A defesa do primado da música instrumental sobre a música vocal (e da música em geral sobre as artes plásticas) nestes autores acentuava, assim, não apenas a natureza metafísica da música, como também a sua anterioridade em relação à linguagem e à diversidade das línguas, o que lhe concedia a capacidade de falar do inefável ou daquilo que a linguagem conceptual não pode exprimir. Para Schopenhauer, a música não imita o mundo das representações nem os sentimentos dos homens e a sua origem não é uma imitação da linguagem

11 O musicólogo Carl Dahlhaus esclareceu que o conceito de "música absoluta" ou "pura" foi a ideia fundamental da estética musical na época clássica e romântica, sendo proveniente da poesia e filosofia do romantismo alemão. Esse conceito consiste na associação de uma música separada de textos, programas e funções com a expressão ou o pressentimento do "absoluto": trata-se da ideia de que se pode pensar através da música e dos sons tal como o literato pensa com as palavras. De acordo com Dahlhaus, inicialmente a música instrumental, privada de conceito, objecto ou finalidade, aparecia como vazia e sem conteúdo, por exemplo, para Rousseau, que defendeu o modelo da música vocal recorrendo à teoria dos afectos e à estética do sentimento. Depois surge a tendência para contradizer a caracterização sentimental da música ou para converter esses afectos concretos em sentimentos mais difusos, como o fazem Novalis ou Friedrich Schlegel, contrariando a tese utilitarista. Nasce, assim, o princípio da autonomia, em nome do qual a música instrumental - até aí considerada como uma versão deficiente da música vocal - acedeu à dignidade de paradigma musical: o que parecia inicialmente uma carência, a ausência de conceito e de objecto próprio, é então declarado como vantagem e exprime-se a convicção de que a música instrumental formula de modo puro e directo a essência da música, porque é sem conceito, objecto ou função — a música instrumental passa, enquanto simples estrutura, a valer por si mesma e a formar um "mundo à parte". Cf. DAHLHAUS, C. Lidée de la musique absolue. Genève: Contrechamps, 2006, sobretudo capítulo I, "La musique pure comme paradigme esthétique" (pp. 11-22). Ainda sobre a estética musical romântica e sua influência em Nietzsche e Schopenhauer, cf. DUFOUR, É., op. cit., cap. I, "Le statut de la musique dans le romantisme allemand" (pp. 21-39). 
humana através do canto e da melodia: ela é primeira e anterior aos fenómenos e primeira e anterior em relação às palavras cantadas. Por esta razão, no $\$ 52$ de $O$ Mundo como Vontade e Representação Schopenhauer afirma que a origem do canto e da ópera reside no esforço de dar figuras, imagens, a um mundo que é puramente musical, nunca devendo as palavras do canto e do libreto esquecer a sua subordinação à música, pois isso transformá-la-ia "num simples meio de expressão ${ }^{12}$. No capítulo dos Suplementos dedicado ao mesmo parágrafo, Schopenhauer insiste neste aspecto: a música "não precisa das palavras de um poema ou da acção de uma ópera", para ela "a própria voz humana não é senão originariamente e por essência um som modificado", como o som de um instrumento, e "quando incorporadas na música, as palavras devem sujeitarse a todas as exigências do som", pois a música "está na mesma relação com o texto e a acção do que o geral com o particular, a regra com o exemplo, sendo muito mais conveniente compor o texto para a música do que a música para o texto"13. Assim, a música puramente instrumental de uma sinfonia de Beethoven, por exemplo, suscitando embora em nós a visão de toda a espécie de cenas e formas da vida e da natureza, deve contudo ser escutada na sua "pureza imediata" e não ser "sobrecarregada por um elemento heterogéneo e arbitrário"14, quer dizer, representativo e linguístico.

No entanto, e apesar da primazia da música em relação aos elementos imagéticos e linguísticos no pensamento de Schopenhauer, este filósofo não rejeitou uma matriz visual da experiência estética, em particular da experiência de criação artística, quer dizer, da experiência do génio, concebendo Schopenhauer a sua articulação com o mundo sonoro e musical da vontade ${ }^{15}$. É importante sublinhar

12 SCHOPENHAUER, A. Sämtliche Werke. Stuttgart/Frankfurt am Main: Cotta-Insel Verlag, 1960/1965, v.I/v.II (organizado por Wolfgang von Löhneysen), v. I, p. 365 (nossa tradução).

13 Sämtliche Werke, op.cit., Band II, Kapitel 39 “Zur Metaphysik der Musik”, p. 575 ( nossa tradução).

14 Idem, p. 577 ( nossa tradução).

15 No seu estudo Une philosophie du conflit. Études sur Schopenhauer Sandro Barbera 
este aspecto, pois a articulação do sonoro com o visual remete para a solução encontrada por Nietzsche para aquilo a que, no início d'O nascimento da tragédia, chamou a "tremenda oposição entre a arte do escultor, a apolínea, e a arte da música, isenta de imagens". $\mathrm{O}$ elemento visual foi pensado por Nietzsche como pertencendo ao domínio apolíneo "intermédio e visível" que nos resgata "da fusão directa com a música dionisíaca", ou seja, a partir da concepção de uma música em relação à qual o ouvinte oscila entre adesão e distância, embriaguez e auto-domínio, celebrando, não uma "fusão", mas "a união fraterna de Apolo e Dioniso" (GT/NT 24, KSA 1.149-54). N'O nascimento da tragédia a visão apolínea consubstanciada no mito rompe o estado letárgico de identificação com o Uno primordial, indicando a possibilidade de uma protecção em relação à ameaça de destruição individual que a embriaguez dionisíaca representa. Assim, a questão de saber se, n'O nascimento da tragédia, a música pode existir sem a linguagem ou sem as imagens do drama corresponde à pergunta pela possibilidade da autonomia do dionisíaco ${ }^{16}$. Ou seja, a questão pode ser colocada nos termos da possibilidade da autonomia ou independência da música relativamente à linguagem e às aparências apolíneas. Ora, apesar da filiação schopenhaueriana reclamada por Nietzsche na primeira obra que publicou, $O$ nascimento da tragédia não parece autorizar a defesa dessa autonomia, já recusada no texto póstumo

\footnotetext{
discute a primazia da música no pensamento schopenhaueriano, defendendo que, no ponto de universalidade extrema que aquela personifica, o próprio valor simbólico da Ideia já não pode desempenhar nenhum papel: "Fundado na noção de ideia como imagem simbólica, o 'classicismo' de Schopenhauer não se revela como oposto ao 'romantismo' da sua estética musical - como se o terceiro livro fosse formado por dois ramos de origem distinta, um proveniente da atmosfera do classicismo de Weimar, o outro do romantismo de Wackenroder e Tieck —, mas este classicismo é antes um objecto de ironia, minado no seu interior pela intenção ética inicial da contemplação estética. [...] a contemplação estética visa sublinhar a incompatibilidade com o fenómeno, a sua neutralização, para fazer valer uma dimensão de total alteridade". Cf. BARBERA, S. Une philosophie du conflit. Études sur Schopenhauer. PUF : Paris 2004, cap. IV, "La contemplation, le génie et le système des arts", pp. 129-153. 16 É a hipótese de Éric Dufour, que subscrevemos aqui. Cf. DUFOUR, É. op. cit., cap. IV “La 'métaphysique de la musique' dans la Naissance de la tragédie” (pp. 72-97).
} 
citado acima. Se a música é a única arte dionisíaca porque mostra como cada fenómeno individualizado acaba por se dissolver no elemento que o gerou seria, contudo, falso defender que, enquanto arte dionisíaca, a música exclui ou não convoca uma participação do elemento apolíneo. A verdade é que, se o dionisíaco afecta o apolíneo, deformando-o ou dissolvendo os seus limites, o apolíneo, por sua vez, responde à força dissolutora dionisíaca com a força da individuação, gerando formas limitadas a partir de um fundo informe. Assim, uma autonomia ou auto-suficiência do dionisíaco não está em causa para Nietzsche, que concebe a articulação - isto é, nem a "fusão", nem uma dicotomia - deste com o elemento apolíneo. E isso significa que a arte dionisíaca não é o outro absoluto da arte apolínea, justamente porque não é "absoluta", mas aquela onde as formas apolíneas encontram o seu limite, o fundo irrepresentável e ilimitado que só pode, por seu turno, ser conhecido através de delimitações em palavras, mitos ou figuras visíveis. Dito de outro modo, Nietzsche não defende nem uma música pura e autónoma, nem uma música cujo sentido reside puramente no drama, no seu lado conceptual e visual - o que se torna ainda mais claro nas suas obras subsequentes, e muito em especial nas análises que dedica à obra de Wagner.

A articulação do musical com o visual e conceptual ou mítico, quer dizer, nos termos d'O nascimento da tragédia, do dionisíaco com o apolíneo, serviu de base tanto para a tese de Nietzsche sobre a arte trágica, como para a legitimação da ideia de que o drama musical de Wagner $^{17}$ representava um renascimento do espírito trágico na arte moderna europeia. Mas, na verdade, o problema dessa articulação norteará toda a reflexão de Nietzsche sobre a música e também sobre a música de Wagner no momento em que

17 Acerca da noção de Musikdrama e sua distinção da noção de "ópera” em Wagner, cf. o artigo de Lydia Goehr no volume SORGNER, S. L.; BIRX, H. J.; KNOEPFFLER, N. (org.). Wagner und Nietzsche. Kultur - Werk - Wirkung. Ein Handbuch. Reinbek bei Hamburg: Rowohlt Taschenbuch Verlag, 2008, p. 215-248. 
a obra deste compositor deixou de concentrar as suas esperanças num renascimento da tragédia, passando a personificar, ao invés, o exemplo máximo da decadência da música europeia moderna. Este revés é patente nos textos de Nietzsche pelo menos desde 1874, em particular nos fragmentos póstumos desse ano onde se encontram já muitas das críticas que Nietzsche irá fazer à obra de Wagner de modo mais sistemático nos escritos mais tardios ${ }^{18}$. O problema de fundo novamente abordado por Nietzsche, agora sem recorrer às noções de dionisíaco e apolíneo, é a recusa da ideia de que a música é uma expressão de conteúdos extra-musicais — seja ela considerada "pura", "autónoma" e livre do âmbito linguístico, ou como um mero ingrediente de um drama musical.

Ora, quer num caso, quer no outro o alvo de Nietzsche é a reivindicação do estatuto de "música absoluta" por uma música que carece precisamente da articulação entre o sonoro e o linguístico ou discursivo que o dionisíaco e o apolíneo encarnavam n'O nascimento da tragédia. Nas secções 215 e 217 de Humano, demasiado humano I Nietzsche descreve essa carência como sendo decorrente de uma progressiva "intelectualização dos sentidos" (MA I/ HH I 217, KSA 2.177-8) que tendeu acentuar a exigência de uma separação, emancipação ou autonomia da esfera musical. Ora, como escreve Nietzsche, a música não tem outro sentido para além do seu sentido sonoro, musical, ou seja, “em si, nenhuma música é profunda, nem significativa, não fala da vontade ou da coisa em si." (MA I/HH I 215, KSA 2.175) A "música absoluta”, portanto, é ou "uma forma em si, (...) ou o simbolismo das formas cuja linguagem é compreendida mesmo sem poesia" (MA I/HH I 215, KSA 2.175), quer dizer, sem

18 Refiro-me, em particular, à definição de Wagner como um "actor" (KSA 7, Nachlass/FP 31[52]) e "tirano" (KSA 7, Nachlass/FP 32[31] e [34]), que desenvolve uma arte de massas (KSA 7, Nachlass / FP 32[61]), que fez da música um meio e não um fim (KSA 7, Nachlass/ FP 32[52]) e cuja arte a arte consiste, tal como a religião, numa negação do mundo em que vivemos (KSA 7, Nachlass/FP 32[44]:"a arte de Wagner nega este mundo, não o transfigura"). Sobre as críticas de Nietzsche a Wagner neste período, cf. DUFOUR, É., op. cit., Deuxième partie, chap. I "L'ambigüité du discours de Nietzsche en 1874-1876" (pp. 157-168). 
as palavras do drama. No primeiro caso sentimos "a música de modo puramente formal", isto é, de modo simplesmente sonoro, como mera modulação de sons que, porém, para Nietzsche, não exprimem aquilo que as palavras não podem dizer (o inefável ou um além da linguagem terrena a que só a música daria acesso). No segundo caso, compreendemos a música "simbolicamente", ou seja, através do seu conteúdo extra-musical (mitológico, simbólico, sentimental ou outro), depois de "a forma musical estar toda entretecida com fios conceptuais e sentimentais" (MA I/HH I 215, KSA 2.175), ou seja, depois de o intelecto "introduzir" significações determinadas no som, fazendo com que a música transmita informações e sentimentos ao ouvinte de modo a que este fique instruído sobre o que deve pensar, sentir e compreender quando a escuta. Ambos os casos contribuem para a progressiva "intelectualização" que os sentidos sofreram ao longo da história da música e que fez com que, quando a escutamos, perguntemos, não pelo que "é" aquilo que ouvimos, mas pelo que aquilo "significa" (MA I/HH I 217, KSA 2.177-8), quer dizer, que sentimento ou ideia devemos escutar naqueles sons. Esse processo de intelectualização empobreceu, portanto, a experiência de ouvir propriamente a música, a experiência da sua descoberta a partir dos sentidos e o prazer propriamente musical e sonoro que exige uma disponibilidade não determinada à partida por sentidos e sentimentos estranhos que são impostos àquilo que se está a ouvir. Os nossos ouvidos, conclui Nietzsche, tornaram-se assim "grosseiros" (MA I/HH I 217, KSA 2.177-8) e incapazes de um reconhecimento que não seja conceptual, simbólico ou sentimental.

A crítica à "intelectualização dos sentidos" corresponde à crítica da subordinação da sensibilidade ao intelecto discursivo, que, no caso da música, equivale à subordinação do ouvido e da escuta a sentidos extra-musicais (metafísicos ou não). A "intelectualização dos sentidos" impede aquilo que em termos kantianos se poderia definir como uma complementaridade entre sensibilidade e intelecto e uma colaboração de ambos no prazer estético, ficando a primeira refém do segundo e a música refém de um sentido que a excede. 
Ora, foi justamente isto que Nietzsche descobriu que a arte de Wagner promovia e um dos motivos das suas críticas àquela música. N'O nascimento da tragédia, como se disse já, a música de Wagner parecia poder incorporar uma crítica dos efeitos da ausência de articulação entre dionisíaco e apolíneo na cultura europeia, recuperando essa mesma articulação com consequências que excederiam o âmbito estritamente estético e artístico (ou o sentido mais estrito para que estes âmbitos foram sendo remetidos). E é verdade que Wagner começou por entender a música como uma arte que permitia estabelecer transformações culturais e políticas, integrando as dimensões afectiva e inteligível da vida humana ${ }^{19}$. No entanto, o entendimento que Wagner tinha da música, da sua natureza e dos seus propósitos foi-se alterando e, influenciado pela leitura de Schopenhauer, o compositor acabou por se tornar pessimista em relação ao seu poder de transformação colectivo e por atribuir à música uma dignidade metafísica e um poder redentor. Nietzsche não pôde seguir Wagner nesta evolução da sua compreensão da música cujas consequências, em vez de conduzirem a um futuro expurgado de ilusões metafísicas e reforçarem visões anti-teleológicas e antiredentoras da existência, faziam da música e do drama musical um substituto da religião. Ou seja, já não se trataria de uma música

19 Sobre as aspirações da música de Wagner a instituir-se como "música do futuro" e sobre a utopia da obra de arte total, cf., além dos textos teóricos do próprio compositor (nomeadamente, WAGNER, R. A arte e a revolução. Trad. José Miranda Justo. Lisboa: Antígona, 2000 e WAGNER, R. A obra de arte do futuro. Trad. José Miranda Justo: Lisboa: Antígona, 2003), os estudos GOEHR, L. The Quest for Voice. Music, Politics, and the Limits of Philosophy. Oxford, Oxford University Press, 1998 e PICARD, T. L'art total. Grandeur et misère d'une utopie (autor de Wagner). Rennes: Presses Universitaires de Rennes, 2006. O artigo de Marco Brusotti no volume SORGNER, S. L.; BIRX, H. J.; KNOEPFFLER, N. (org.). Wagner und Nietzsche. Kultur - Werk - Wirkung. Ein Handbuch. Reinbek bei Hamburg: Rowohlt Taschenbuch Verlag, 2008 é particularmente elucidativo acerca das aspirações de ordem política que animaram Wagner ao longo da sua vida e dos seus reflexos na obra artística e teórica do compositor (pp. 265-286). Para um estudo detalhado da evolução do pensamento de Nietzsche e de Wagner a respeito do seu entendimento do conceito de „cultura“, cf. ainda o capítulo „Kultur germanique et Zivilisation latine dans la réflexion de Wagner et de Nietzsche“ da obra CAMPIONI, G. Les lectures françaises de Nietzsche. Paris: PUF, 2001 , p. 109-128. 
nascida do espírito trágico e cuja experiência permitia afirmar a existência humana a despeito de todo o sofrimento que ela acarreta, mas antes de uma música que, fingindo transcendência, tornava os seus ouvintes insatisfeitos com a vida, levando-os a negá-la.

A tendência para dotar a música de um valor extra-musical encontra-se sobretudo na criação wagneriana de uma mitologia da redenção (manifesta em Parsifal) e de uma narrativa acerca das origens da música, que constitui, em rigor, uma narrativa acerca das origens do mundo (desenvolvida ao longo da Tetralogia) ${ }^{20}$. Através das dimensões mitológica e simbólica da sua música dramática ${ }^{21}$, Wagner dotou as suas composições de um sentido extra-musical que subordinava a experiência da escuta a um simples meio de aceder a um sentido previamente estipulado, a uma interpretação do mundo previamente estabelecida. Fazendo-o, incorreu na ten-

20 Acerca desta última, cf. a conferência dada por Thomas Mann em 1937 em Zurique intitulada "Richard Wagner e o Anel do Nibelungo", onde Mann defende - não de um modo isento e rigoroso, como reconheceria mais tarde — que Wagner entendia que a arte não se liga à contingência histórica, mas à verdade eterna, o que explica que escolhesse narrar a história mítica de Siegfried em vez de tratar de uma figura histórica. A lenda de Siegfried, o herói primitivo, a natureza humana na sua pureza eterna tratada fora de qualquer convenção, eliminaria as impurezas históricas e restabeleceria a verdade humana tal como a espontaneidade popular a tinha gerado. Assim, ainda de acordo com Mann, Wagner tratou o passado como um futuro ao qual se deveria regressar, remontando às fontes do mito e à origem de todas as coisas, acabando por "construir uma cosmogonia musical" e por "representar a origem do mundo e o seu fim". Thomas Mann baseia-se na carta que o músico escreveu a Liszt em 20/11/1851 para mostrar que tal construção mitológica foi motivada por razões, não ideológicas (e foi justamente esta a consequência da sua falta de isenção e rigor), mas musicais, e que Wagner não pretendia apenas escrever uma música mítica, mas criar o próprio mito da música, compor uma filosofia mítica e uma génese da música, articulando no acorde de mi bemol com que inicia a sua Tetralogia as inúmeras partes de um mundo de símbolos musicais. Para Wagner, "mito" significava, assim, a língua de um povo ainda capaz de criação poética, a ausência de cultura ou a nobreza, a pureza, "o humano absoluto" que é verdadeiramente o tema da inspiração musical. MANN, T, Noblesse de l'esprit, Paris: Albin Michel, 1960, p. 153-183. A respeito da noção de "humano" nos textos de Wagner, cf. ainda GOEHR, L., op. cit., pp. 36-37.

21 Acerca da noção de Musikdrama e sua distinção da noção de "ópera" em Wagner, cf. o artigo de Lydia Goehr no volume SORGNER, S. L.; BIRX, H. J.; KNOEPFFLER, N. (org.). Wagner und Nietzsche. Kultur — Werk - Wirkung. Ein Handbuch. Reinbek bei Hamburg: Rowohlt Taschenbuch Verlag, 2008, p. 215-248. 
dência acima descrita e que Nietzsche descreveu como sendo uma primazia do significado daquilo que é ouvido sobre a pergunta por aquilo que efectivamente está a ser ouvido, ou seja, como uma das manifestações da intelectualização do sentido da audição. É neste contexto que se pode compreender em que medida a escuta da música de Wagner por Nietzsche foi afectada pela crítica que faz da mitologia suspeita que encontrou em Bayreuth. Convém, no entanto, sublinhar que, mesmo nas páginas mais críticas que escreveu contra Wagner, encontramos sempre uma ambivalência em relação a uma música que tocara Nietzsche tão profundamente ${ }^{22}$. O Wagner "actor", "histrião", teatral e artista de massas também escreveu "a música mais solitária que existe" (NW/NW Objecções, KSA 6.41820); o "Cagliostro da modernidade" (WA/CW 6, KSA 6.23-6), cuja obra move as multidões que confundem o belo com o colossal, foi também "o mestre das nuances", "o nosso maior miniaturista da música": "Ninguém se lhe compara nas cores do outono tardio, na felicidade indizivelmente comovente dos últimos, dos mais breves prazeres; ele conhece os sons que exprimem aquelas terríveis e perturbantes meia-noites da alma onde causa e efeito parecem escapar a todas as leis e onde, a cada instante, qualquer coisa pode nascer do 'nada'. Melhor do que ninguém, ele sabe haurir o mais profundo da felicidade humana, como que o cálice esvaziado, onde finalmente, infernalmente, as gotas mais amargadas se juntaram às mais doces" (NW/NW O que admiro, KSA 6.417-8).

Estas palavras parecem mitigar a rejeição de Nietzsche, mas não escamoteiam duas ordens de razões que estiveram na base do seu afastamento da arte de Wagner. A primeira pode ser formulada nos termos d'O nascimento da tragédia: se, como se disse acima, o mito é o elemento que protege o ouvinte do poder musical dissolutor da individualidade, depois de assistir ao festival de Bayreuth

22 Tal como é defendido no belo estudo de Marie-Louise Mallet "Nietzsche — La nuit de l'écoute”. In: MALLET, M-L. La musique en respect. Paris: Galilée, 2002, p. 139-192. 
Branco, M. J.

Nietzsche não pôde continuar a aceitar o escudo protector de uma mitologia forjada e carregada de peso ideológico, quer dizer, de uma mitologia não nascida do espírito da música. Em rigor, os mitos criados por Wagner não apenas não protegem do poder dissolutor da música, como o promovem através da ideologia que servem. Ora, isto significou, para Nietzsche, que das composições wagnerianas sobrava apenas a música como elemento passível de apreciação. Mas acontece que se a escuta "simbólica" (para voltar aos termos de Humano, demasiado humano) foi minada por uma falsa mitologia, a escuta puramente "formal" também não é satisfatória, representando igualmente um "perigo", tanto para o sentido da audição, como para o intelecto. A razão é que a música de Wagner carece de "medida" (NW O lado perigoso de Wagner, KSA 6.421-2), daquilo que Nietzsche identifica como o "contraste entre a corrente de ar fresco nascida da ponderação e o sopro morno do entusiasmo que faz o encanto poderoso de toda a boa música." (MA II WS/HH II AS 134) O que isto significa é que, também de um ponto de vista estritamente musical, Nietzsche lamenta a perda do elemento apolíneo na música, quer dizer, a perda da forma que permite orientação, "ponderação" e sobriedade. O melhor exemplo desta perda nas composições musicais de Wagner encontrase na invenção da "melodia infinita" e em inovações rítmicas que desorientam o ouvinte, obrigando-o a vogar sem apoio num mar de sons, levado pela corrente sem qualquer controlo crítico, desprovido de "lucidez" (MA II WS/HH II AS 134), ou seja, da possibilidade de pensar. É neste sentido que, também de um ponto de vista estritamente sonoro ou formal, a arte de Wagner ameaça o intelecto, coagindo os seus ouvintes a subjugar a sua "lucidez" a uma massa de sons que não permite pensar. A arte de Wagner é, portanto, como um "narcótico" que adormece os sentidos e embota o espírito, partindo do imperativo "sobretudo, nem um pensamento!" (WA/CW 6, KSA 6.23-6). A sua lógica é: "o que nos abala é forte, o que nos exalta é divino, o que nos faz pressentir o inefável é profundo" (WA/CW 6, KSA 6.23-6). 
Assim, se, por um lado, Wagner subordina a música propriamente dita a um sentido que a excede e que é mitológico, simbólico e da ordem do discurso e da linguagem, ou seja, se a sua arte, em última análise, não afirma, mas nega a música e a escuta musical — na convicção de que aquela música "é muito mais que música, infinitamente mais que música" (WA/CW 10, KSA 6.35-7) —, não é menos verdade que, do ponto de vista formal e composicional as suas obras não são também uma "música de carácter afirmativo" (EH/EH O caso Wagner 1, KSA 6.357-8) porque exercem uma estimulação tal dos sentidos que os conduz, paradoxalmente, à anestesia. Ao escutar Wagner, os ouvidos não podem senão obedecer submetendo-se à violência de efeitos que se exercem sem lhes dar "descanso", aquele "descanso da melodia que é o prazer mais sublime e fatigante" (FW/GC 80, KSA 3.4357). Expostos a tanto ruído, ao "Sursum! Bumbum!" (WA/CW 6, KSA 23-6) wagneriano os ouvidos tornam-se surdos, espoliados da sua capacidade de ouvir, não lhes restando senão recorrer ao sentido extra-musical para poderem aceder ao sentido, ao significado daquelas obras. Subordinando a música a um sentido extra-musical previamente estabelecido e narcotizando os sentidos através de estratégias de composição musical, Wagner agudizou, portanto, a tendência histórica da intelectualização dos sentidos e promove uma música, não dionisíaca, mas negadora da experiência da escuta musical e da própria música. Dito de outro modo, a música de Wagner tiraniza corpo e espírito, sentidos e intelecto, impedindo o seu livre jogo por ocasião da escuta musical, quer dizer, impedindo o exercício da liberdade que a música pode e deve favorecer.

3.

Em última análise, é aqui que as críticas de Nietzsche a Wagner se concentram, é este o ponto de fuga que age em cada variação 
das suas censuras ao compositor. Nietzsche compreendeu que a música de Wagner serve exigências autoritárias que interditam uma relação livre do ouvinte com aquilo que ouve. E na medida em que a música só existe quando é ouvida, a música de Wagner nega-se, assim, a si mesma enquanto música porque exige dos seus ouvintes que não a escutem. Pelo contrário, defende ainda Nietzsche, uma música afirmadora é aquela que "torna o espírito livre", que "dá asas ao pensamento" que suscita o "pathos filosófico" (WA/CW 1, KSA 6.13-4). Ou seja, ela dirige-se aos sentidos de uma forma tal que estes são afirmados na sua liberdade e capacidade de sentir e de gerar pensamentos a partir da configuração sonora que os afecta, transfigurando-a e transfigurando-se num jogo em que as partes não se anulam, nem se fundem. Esta música, que Nietzsche identifica com a Carmen de Bizet, seria, então, uma música que toma o ouvinte "por inteligente, por músico" e Nietzsche descreve assim o que acontece quando a ouve: "durante aquele tempo, muitos outros pensamentos me vêm à cabeça... Já alguém reparou a que ponto a música torna o espírito livre? Que dá asas ao pensamento? E que nos tornamos tanto mais filósofos quanto mais nos tornarmos músicos?" (WA/CW 1, KSA 6.13-4).

Mas podemos perguntar se esta descrição não equivale à defesa da intelectualização dos sentidos que Nietzsche parecia condenar. Uma música que faz pensar não será uma música intelectualizada? A verdade é que só o seria de um ponto de vista que separa o ouvir do pensar numa dicotomia que considera os dois âmbitos irredutíveis um ao outro, em vez de admitir, como a filosofia de Nietzsche admite, a convivência livre, a "união fraterna" entre pensamento e sensibilidade ou, para sermos mais rigorosos, entre pensamento e corpo. Assim, declarar, como Nietzsche declara, que a música pode fazer-nos pensar, corresponde precisamente ao contrário da tendência intelectualizante da estética moderna no contexto de uma filosofia para a qual não existe uma faculdade de pensamento irredutível ao corpo. Para a mesma filosofia, o pensamento e a vida orgânica articulam-se em experiências que não são 
redutíveis a discursos já estabelecidos, a saberes especializados e já estabilizados, já determinados. É precisamente isto que garante a especificidade e a liberdade do discurso filosófico, que Nietzsche baptiza como "psicofisiológico" (JGB/BM 23, KSA 6.389), fundamentando a definição dos seres humanos como aqueles "animais que ainda não estão fixados" (JGB/BM 62, KSA 6.81-3).

Para Nietzsche, a experiência de ouvir música pode promover o exercício do pensamento e da liberdade justamente quando exige, no momento da sua escuta, uma suspensão das categorias já existentes e uma atenção que não é uma imposição de sentidos ou significados já conhecidos, mas aquilo que Nietzsche define como um exercício de aprendizagem e de auto-aprendizagem (FW/ GC 334, KSA 559-60). Se, quando ouvimos um discurso a nossa escuta se dirige a um sentido que se torna presente para além do som, quando ouvimos música, pelo contrário, o que se apresenta para ouvir é tanto o som como o sentido. Por essa razão, no primeiro caso, o som parece tendencialmente desaparecer ou ser indiferente à mensagem que procuramos compreender, enquanto que, no segundo, o sentido manifesta-se, por assim dizer, à velocidade do som, coincidindo tendencialmente com ele, e a escuta dirige-se e é suscitada pelo movimento onde o som e o sentido ressoam um no outro ou um pelo outro numa espécie de espaço comum ${ }^{23}$. Este espaço é uma estrutura aberta que vai sendo continuamente tecida entre o ouvido e a música que soa porque esta última não se apresenta imediatamente a nós na sua totalidade. O que é próprio da música é ir chegando, é o seu chegar e passar num fluxo que vai abrindo espaço em nós e fora de nós, um fluxo "onde o tempo se transforma em espaço" "24. É neste sentido que não é exacto falar da música como sendo um objecto, no sentido que a filosofia moderna deu a este conceito, pois ela não está à partida dada diante daquilo que essa

23 Seguimos as palavras de Jean-Luc Nancy no ensaio À l'écoute. Paris: Galilée, 2002.

24 Parsifal, Acto I, cena I: "zum Raum wird hier die Zeit". 
filosofia entendeu ser um sujeito. E em rigor, aliás, nem a música é um objecto, nem o seu ouvinte pode ser entendido como um sujeito dotado de um conjunto de faculdades determinadas de conhecimento que aplica à experiência empírica de ouvir música determinando o que ela é. Ao ouvir música, isso a que a tradição moderna chamou um sujeito revela-se também ele como algo que não está já dado e determinado à partida, constituindo-se em diálogo com os sons que lhe vão chegando. Nesta experiência ele pode descobrir-se a si mesmo como sendo o lugar onde a música ressoa, ou seja, como um espaço de acolhimento de outra coisa, que se vai tecendo e acontecendo à medida que essa outra coisa vai chegando. A ser assim, acederá a si próprio como qualquer coisa que está em devir ou a chegar, quer dizer, como algo que não está ainda fixado, determinado, conhecido, numa experiência que, num poema dedicado às Variações Goldberg, Jorge de Sena descreveu assim:

A música é só música, eu sei. Não há outros termos em que falar dela a não ser que ela mesma seja menos que si mesma. Mas o caso é que falar de música em tais termos é como descrever um quadro em cores e formas e volumes, sem mostrá-lo ou sem sequer havê-lo visto alguma vez. Vejamo-lo, bem sei, calados, vendo. E se a música for música, ouçamo-la e mais nada. No entanto, nenhum silêncio recolhido nos persiste para além de alguns minutos. E não dura na memória como silêncio. $\mathrm{Ou}$, se dura, esse silêncio cala a própria música que adora. Porque a música não é silêncio mas silêncio que anuncia ou prenuncia o som e o ritmo. Se os sons, porém, não são de devaneio, e sim a inteligência que no abstracto busca ad infinitum combinações possíveis bem que ilimitadas; se tudo se organiza como a variada imagem 
de uma ideia despojada de sentido;

se tudo soa como a própria liberdade dos acasos lógicos

que os grupos, e os grandes números, e as proporções

conhecem necessários; se tudo repercute como

em cânones cada vez mais complexos que não desenvolvem

um raciocínio mas o transformam de um si mesmo em si;

se tudo se acumula menos como som que como pedras

esculpidas em volutas brancas e douradas cujos

recantos de sombra são um trompe l'oeil

para que elas mais sejam em paredes curvas;

se uma alegria é força de viver e de inventar e de

bater nas teclas em cascatas de ordem;

e se tudo existiu na música para tal triunfo

e dele descende tudo o que de arquitectura

possa existir em notas sem sentido - COMO

não proclamar que essa grandeza imensa

não se comove com íntimos segredos (mesmo implica

que não haja segredo em nada que se faça

a não ser o espanto de fazer-se aquilo),

é como que uma cúpula de som dentro da qual

possamos ter consciência de que o homem é, por vezes,

maior do que si mesmo. E que nada no mundo,

ainda que volte ao tema inicial, repete

o que foi proposto como tema para

se transformar no tempo que contém. Quando, no fim, aquele tema torna não é para encerrar

num círculo fechado uma odisseia em teclas, mas para colocar-nos ante a lucidez

de que não há regresso após tanta invenção.

Nem a música, nem nós, somos os mesmos já.

Não porque o tempo passe, ou porque a cúpula se erga,

para sempre, entre nós e nós próprios. Não. Mas sim porque

o virtual de um pensamento se tornou ali

uma evidência: se tornou concreto. 
Um concreto de coisas exteriores - e o espanto é esse igual ao que de abstracto têm as interiores que o sejam.

Será que alguma vez, senão aqui, aconteceu tamanha suspensão da realidade a ponto de real e virtual serem idênticos, e de nós não sermos mais o quem que ouve, mas quem é? A ponto de nós termos sido música somente?

Este poema prova que se o que é próprio da música enquanto acontecimento sonoro (não visível e não linguístico) é o facto de ela não poder ser antecipada, isso não significa, porém, nem que a música vem de outro mundo, nem que ela é indizível. A música é uma criação humana e dirige-se aos ouvidos dos homens, só existindo propriamente quando soa ou ressoa em quem a escuta na sua singularidade concreta, empírica. Neste sentido a música existe, na realidade, mais aquém do que além das palavras e categorias que, de acordo com a filosofia de Nietzsche, falsificam o que há de singular em cada coisa que existe e em todas as nossas experiências. É também por isso que, no que à música diz respeito, a revalorização do sensível que é "a palavra de ordem da filosofia nietzschiana" ${ }^{25}$ consiste precisamente em fazer valer o que na música é irredutível a todo o discurso já constituído de modo a que, ao escutá-la, nos sintamos livres para pensar em modos de a dizer (e escrever, como fizeram tanto Nietzsche como Sena). É neste sentido que, para Nietzsche, a música promove ou deve promover um contínuo exercício do pensamento, o "pathos da filosofia", que é um exercício da liberdade e gerador de novas possibilidades discursivas e conceptuais. Se a música não fala, ela não é, pelo menos para Nietzsche, uma expressão do inefável, nem

25 Expressão de Éric Dufour no capítulo "La pensée et son autre dans la musique", op. cit., p. 292-300. 
impede a possibilidade de darmos palavras àquilo que ouvimos. Um fragmento póstumo de 1881 (KSA 9.582, Nachlass/FP 12[36]), com o qual gostaríamos de concluir, é disto esclarecedor:

A música é o meu e o nosso percursor — falar de um modo assim tão pessoal e tão bem e de forma tão nobre! Não podemos dizer quantas coisas ainda não encontraram nome e pensamento - é isso que a nossa música prova - e não que não existem pensamentos nem palavras para tudo isso.

\begin{abstract}
The aim of this paper is to establish the reasons of music's primacy in Nietzsche's philosophy. By presenting the notion of "absolute music" and it's consequences in modern aedthetics, namely in Schopenhauer's and Wagner's works, we will try to clarify the reasons of Nietzsche's distancing from this very notion and to show how his criticisms of a "metaphysics of music" gives birth to an understanding of the experience of hearing music as an exercise of freedom that promotes philosophical thinking.
\end{abstract}

Keywords: music - philosophy - language - freedom - Wagner

\title{
referências bibliográficas:
}

BARBERA, S. Une philosophie du conflit. Études sur Schopenhauer. PUF : Paris 2004.

BOWIE, A. Music, Philosophy and Modernity. Cambridge University Press, 2007.

CAMPIONI, G. Les lectures françaises de Nietzsche. Paris: PUF, 2001.

CONSTÂNCIO, J.; BRANCO, M.J.M. (orgs.)., As the Spider Spins: Essays on Nietzsche's Critique and Use of Language. Berlin/ Boston/NY: Walter de Gruyter, 2012.

DAHLHAUS, C. L’idée de la musique absolue. Genève: Contrechamps, 2006.

DUFOUR, É. L'esthétique musicale de Nietzsche. Presses Universitaires du Septentrion, 2005.

GERHARDT, V. Pathos und Distanz. Studien zur Philosophie Friedrich Nietzsches. Stuttgart, Reclam, 1988.

GOEHR, L. The Quest for Voice. Music, Politics, and the Limits of Philosophy. Oxford, Oxford University Press, 1998. 
JANZ, C. P. Nietzsche. Biographie Tome I. Enfance, jeunesse, les années bâloises. Paris: Gallimard, 1984. . Nietzsche. Biographie Tome II. Les dernières années bâloises, le libre philosophe. Paris: Gallimard, 1984. . Nietzsche. Biographie Tome III. Les dernières années bâloises, le libre philosophe. Paris: Gallimard, 1985.

KESSLER, M. L'esthétique de Nietzsche. Paris: PUF, 1998.

LACOUE-LABARTHE, P. Le sujet de la philosophie (Typographies I). Paris: AubierFlammarion, 1979. . Musica ficta (Figures de Wagner). Paris: Christian Bourgois Éditeur, 1991.

LIÉBERT, G. Nietzsche et la musique. Paris: PUF, 2000.

MALLET, Marie-Louise. La musique en respect. Paris: Galilée, 2002.

MANN, T. Noblesse de l'esprit. Paris: Albin Michel, 1960.

MEYER, T. Nietzsche und die Kunst. Tübingen, Basel: Francke Verlag, 1993.

NANCY, J. À l'écoute, Paris: Galilée, 2002.

PICARD, T. L'art total. Grandeur et misère d'une utopie (autor de Wagner.) Rennes: Presses Universitaires de Rennes, 2006.

SAFRANSKI, R. Nietzsche. Biographie seines Denkens. Frankfurt am Main: Fischer Taschenbuch Verlag, 2005.

SANTIGO GUERVÓS, L. Arte y Poder. Aproximación a la estética de Nietzsche. Madrid: Trotta, 2004.

SCHOPENHAUER, A. Sämtliche Werke. Stuttgart/Frankfurt am Main: Cotta-Insel Verlag, 1960/1965, v.I/v.II (organizado por Wolfgang von Löhneysen).

SORGNER, S. L.; BIRX, H. J.; KNOEPFFLER, N. (org.). Wagner und Nietzsche. Kultur Werk - Wirkung. Ein Handbuch. Reinbek bei Hamburg: Rowohlt Taschenbuch Verlag, 2008.

WAGNER, R. A arte e a revolução. Trad. José Miranda Justo. Lisboa: Antígona, 2000. . A obra de arte do futuro. Trad. José Miranda Justo. Lisboa: Antígona, 2003.

Artigo recebido para publicação em 10/04/2012. Artigo aceito para publicação em 15/05/2012. 